\title{
Challenges in Transformation of the Professional Development of Academic Staff in Latvia
}

\author{
Sanita Baranova, Indra Dedze, Zanda Rubene \\ University of Latvia, Raina b. 19, Riga, LV 1586, Latvia \\ sanita.baranova@lu.lv; indra.dedze@lu.lv; zanda.rubene@lu.lv
}

\begin{abstract}
The paper analyses the professional development of the academic staff in higher education institutions in Latvia over the last decade. Characterising the history, trends and challenges of the professional development of the academic staff in Latvia in the context of the Bologna process, normative documents of the European and national level pertaining to higher education have been analysed. The paper reveals the framework in the experience of the universities in the implementation of the professional development of the academic staff in Latvia as well as formulates the challenges faced by the academic staff in their professional activity, and the necessary transformations. The experience of institutionalising the professional development of the academic staff in the case of the University of Latvia has been analyzed in detail.
\end{abstract}

Keywords: academic staff, higher education, Bologna process, professional development of the academic staff.

\section{INTRODUCTION}

The political and socioeconomic changes that erupted after the dissolution of the Soviet Union are setting the terrain of the research. The Baltic States made changes from totalitarian to democratic regime. After regaining independence in 1991 the changes affected also the system of education in Latvia. This influenced the professional development of the academic staff for it was important to make changes in the study process as innovations in the university pedagogy and didactics become topical. At first the academic staff was learning from the experience of their Western counterparts, developing gradually their own professional development approaches in the higher education institutions of Latvia. The research context substantially characterises the topical challenges of the formation process of common European Higher Education Area in the light of the Bologna process to the professional activities of the academic staff and its improvement.

The aim of the paper is to analyse the professional development of the academic staff in higher education institutions in Latvia over the last decade. More specifically the paper is focusing on the following research questions:

1) Which are the most important challenges to the professional activity of the academic staff in the context of common European higher education area?

2) Which transformations are needed for the professional development of the academic staff?

The case study design has been chosen for the present study in which several research methods have been used (literature review; analysis of normative documents; structured expert interview) to analyse the experience and challenges of the professional development of the academic staff in Latvia in the context of common European higher education policy. The research period in the paper focuses on the changes in higher education in Latvia during the last ten years.

\section{MATERIALS AND MeTHODS}

In order to find out which the key challenges for the faculty's work are and which transformations are needed in the field of the faculty's professional development in Latvia structured expert interviews were carried out. A structured interview was chosen to ensure an identical interview context and interview stimuli and to be able to present comparatively the obtained information and to analyse it substantially/ validly. 
Four experts from the University of Latvia were invited to participate in the interview - one expert from the field of social and law sciences, humanities, education sciences as well as sciences, life and medicine sciences. All experts have a $\mathrm{PhD}$ degree and at least 10 years' experience in academic work and research. Each of them is the director of the study programme thus they have experience in developing and activating the study programmes, in organizing the work of other faculty, in assessing the quality of the study process. The academic position of the expert in the field of education sciences is professor, the respondents in other fields were associate professors. An important aspect in forming the key informant sample was that 3 experts during the last two years had the participation experience in at least two further education programmes for the academic staff implemented by the University of Latvia and one (the expert in the field of education sciences) had the experience in working out and delivering the further education programmes. Thus it is possible to claim that the respondents have respective knowledge about what is happening in the field of faculty's professional development in the University of Latvia. All experts with their attitude in the present work have proved interest in promoting the growth of the academic staff.

Each expert was asked three questions (two key questions which were supplemented with one specifying additional question) which were determined by the previously performed analysis of the theoretical literature and normative documents:

1) Which, to your mind, are the main challenges in the work of today's university teacher? Has anything changed substantially over the last 10 years?

2) Which, to your mind, are the topical professional development needs of a modern university teacher? What determines them?

3) What changes, to your mind, are necessary in the further education of the university faculty?

\section{RESULTS AND DISCUSSION}

Reforms of higher education system and institutions exert a significant impact also on the increase of the qualification of the academic staff in their field of pedagogical work. Lately the improvement of the quality of teaching is attracting special attention in Europe. It has been admitted on the political level of the European Union that higher education is the prerequisite of innovations, creation of working places and advancement. The report resulting from the study performed by the Group on The Modernisation of Higher Education, European Commission, "Improving the Quality of Teaching and Learning in Europe's Higher Education Institutions" [1] concludes that the quality of teaching and learning should be the centre of the activity in the higher education institutions because achieving the quality and excellence in the field of teaching - learning, research and knowledge transference Europe will be able to compete better in the world's economy.

Thus in many countries of Europe (e.g., Germany, UK, Ireland, Norway, Sweden, Spain, Slovenia, Estonia) having received purposeful governmental and institutional support there already exists best practice of establishing or expanding the existing national or higher education level institutions aimed at improving the quality of the teaching and learning process in higher education institutions [1].

The role of academic staff in higher education institutions in the second decade of the 21 st century experiences radical changes - the work of the academic staff is influenced by education policy, trends promoting the competitiveness of the labour market and the field of economy, the requirement to overcome the uncertainty of the global world, etc. [2]. Being an academic nowadays means to manage in a well-balanced way the study and research process in the higher education institution. The personal views and ideals of the academic staff that he/she possesses as a teacher and researcher are also important. The purpose of the academic staff is through teaching and research to provide the environment for preserving, creating and transmitting knowledge [3].

The new paradigm in the university study process means the shift from teaching to learning, i.e., from teacher-centred study process to student-centred one. It has been emphasized that the course of implementing the changes is determined not only by politicians or the university administration- they mainly depend on the professional performance of the academic staff - what content and teaching learning methods they choose to help students attain the expected learning outcomes.

The World Bank study names quality of teaching and institutional organization of higher education as main problems in the higher education system in Latvia [4]. Several studies from the last decade (e.g., [5], [6]) have indicated the necessity to analyse deeper the quality of professional performance and 
professional development of the academic staff in the context of changes of social and pedagogical culture. This includes the necessity to analyse the conditions of professional work and life of the faculty in Latvia, including retrospective and recognition of future potential. One of the key words also in the context of the Bologna process regarding higher education policy and the performance of higher education institutions as organisations is the quality of education.

Professional development of the academic staff is the guarantee for the sustainability of the higher education institution if the new knowledge, skills and attitudes that the academic staff use in their activities help transform the study process in practice. Transformative learning takes place reconstructing the existing experience not simply supplementing it [7]. Thus the professional development of the academic staff transforms the learning process at the university not only on the individual level but also systemically on the organizational level promoting the professional development transformations of the academic staff.

The issues of the development trends in the theory and practice of the university pedagogy, approaches to the study process, the essence of the university faculty's and student's role and distribution in the study process are activated in the context of the Bologna. The above mentioned creates the key challenges faced by the academic staff of the 21 st century when developing the common European higher education area ([1]; [8]; [9]):

- Europeanization of higher education;

- Management of transformations;

- Balance of teaching and research activities;

- Implementation of the student-centred study process;

- Digitalization of studies;

- Internationalization of studies and mobility.

\subsection{Terrain of the Professional Development of the Academic Staff}

The formation process of the common European education area is the political driving force of the transformations in the higher education system of Latvia. Latvia joined the idea about a common higher education area signing the Bologna declaration in 1999. It is important to stress that Latvia regained its national independence from the Soviet Union only in 1991 and although sweeping reforms started in higher education after 50 years Latvia was being part of the Soviet Union. All this had left a significant impact on the country in general and education in particular. Thus, higher education in Latvia faced numerous challenges in order to close the gap between the vision of a modern university and the reality in which the higher education of Latvia found itself both de jure and de facto [8]. Transformation and improvement of the faculty's professional competence as the implementers of the study process became one of the most topical objectives of higher education institutions.

The development of European Higher Education Area is gaining more importance for developing higher education policy in the country which affects not only institutional development, but also professional development of the academic staff. Faculty faces serious challenges to balance their research, teaching and administrative duties. Initially the ideas of the Bologna process were perceived as referable to the policy level of Europe and national higher education, the work of university administration but gradually the implementation of several ideas of the Bologna process (e.g., implementation of a student-centred study process, formulation and assessment of the learning outcomes) in the study process became more and more important. Nowadays the faculty's professional competence is considered to be a significant factor that ensures quality of higher education in Latvia because the student learning - the process and outcomes largely depend on their performance.

The policy document of the Bologna process that has affected the content of the policy documents of higher education of Latvia as well as the internal normative documents and processes of higher education institutions since its initial publication in 2005 is the European Association for Quality Assurance in Higher Education (ENQA) "The Standards and guidelines for quality assurance in the European Higher Education Area" [10]. These guidelines define that the role of the academic staff of 
the higher education institution changes taking into consideration the diversifying student population and a stronger focus on learning outcomes that require student-centred learning and teaching and the faculty is essential in creating a high quality student experience and enabling the acquisition of knowledge, skills and competences.

Although this document has a recommendation character in the formation of the higher education policy in the national countries, it is a necessary and important agenda document for all the participant countries of the Bologna process, including Latvia. The document points out that higher education institutions have to be aware of the importance of teaching, have to strengthen the link between teaching and research, have to promote the professional development of the teaching staff and have to encourage innovation in teaching methods and the use of new technologies. [10].

It has to be admitted that the development of the faculty's professional quality in the education policy of Latvia has been topical also before joining the Bologna process. In Latvia the development and implementation of the faculty's professional development, first of all, is determined by the "Law on Higher Education Institutions" [11], which has introduced changes in accordance with policy guidelines of establishing common European higher education. According to objectives of higher education institutions defined in Article 5 of the above mentioned law, higher education institutions implement their own internal quality assurance systems within which higher education institutions of Latvia work out the internal rules and regulations of professional development of the academic staff as one of the most essential quality assurance aspects to ensure the qualification of the academic staff and the quality of work. Article 26 of this law, in its turn, defines that the responsibility of the administration of the higher education institution is to care for the work conditions of the staff, to ensure the opportunities to improve qualification of the staff and to re-qualify.

Another normative document in regard to the faculty's professional development in higher education institutions of Latvia is The Cabinet Regulations No 662 [12]. These regulations define that in every period of election in the academic position (every six years) the university and college teachers have to acquire the professional development programmes on either innovations in the higher education system, university didactics or education management (length of the programme - 160 academic hours, at least 60 of them being contact hours). Professional development can also include international mobility and participation in those conferences and seminars relevant to the professional development. The implementation of these Cabinet regulations is the responsibility of the higher education institutions themselves.

In 2000 this norm was included in the Cabinet Regulations No 347 [13] for the first time and it promoted the elaboration of continuous formal further education programmes for the faculty's professional development in several higher education institutions of Latvia (University of Latvia, Riga Technical University, University of Agriculture of Latvia). Then for some time these regulations in regard to faculty's professional development in the field of pedagogical performance lost importance until the report of "Improving the Quality of Teaching and Learning in Europe's Higher Education Institutions" was published [1]. In Latvia this triggered the new understanding of importance of professional qualifications of academic staff [12], as well as the development of new independent accreditation agency - Quality Agency for Higher Education [14]. The work of the Agency has resulted in reconsidering the assessment criteria of the accreditation process of higher education and in improving the normative basis by developing informative and methodological materials that helps the administration of higher education institutions and the academic staff to understand better the external and internal quality assurance issues as an essential prerequisite for the transformations of the study process. [15]. The condition included in these Cabinet regulations stipulates that higher education institutions should ensure the further education opportunities of the academic staff that is evaluated through the self-assessment of the internal quality assurance system of higher education institutions, describing the employment and professional development mechanisms of the academic staff.

Yerevan Ministerial Conference dedicated to the evaluation of the formation of European higher education area (EHEA) has defined that the main mission of the EHEA is enhancement of the quality and relevance of learning and teaching in higher education institutions, promoting pedagogical innovation in student-centred learning environments and in fully exploiting the potential benefits of digital technologies for learning and teaching [16]. Latvia, similar to other countries participating in the Bologna process, has developed its higher education policy by facilitating a stronger link between 
teaching, learning, and research at all study levels and provide incentives for institutions, teachers and students to intensify activities that develop creativity, innovation and entrepreneurship. Yerevan Communiqué [16] also expresses resolution that the expected learning outcomes in the study programmes have to correspond to the needs of the development of the society and be attained through transparent descriptions of learning outcomes and teacher workload, effective learning activities, flexible learning paths and appropriate teaching and assessment methods. In order to achieve all this, it is essential to recognize and support quality teaching, and to provide opportunities for enhancing teaching competences of the academic staff.

In order to analyze how guidelines of European and Latvian higher education policy result in the acquisition of the professional development programmes for the academic staff their experience is further elaborated in the paper.

\subsection{What Does Latvia Do for the Professional Development of the Academic Staff?}

Professional development of the faculty in Latvia is a rather little researched area; however, it has lately become more topical. This is determined by the changes in the above mentioned documents as well as the higher education institutions themselves are more aware of the professional development needs of the faculty and the teachers' own demand for the possibilities to improve their pedagogical competence.

The University of Latvia in 2010 explored the competence of the university teachers, the study programme directors and their professional development. The study revealed that the directors of study programmes are a special group of the university faculty who during the organizational changes of the modern higher education institutions have to cope with diverse administrative challenges. Therefore they should be able to cooperate effectively with other faculty involved in the programme, the administration representatives, students, employees and representatives of other structural units [17].

Later, based on the above findings in 2012 the conception of professional development of university faculty and recommendations for its implementation in the University of Latvia has been developed [6]. It placed the needs of the faculty's professional activities and professional development in the middle, and then identified three forms of adult learning - (formal/institutionalized learning, workplace learning and learning in the work process and self-organized learning) as it meant to address those needs. However, any of the above mentioned organizational forms of learning revealed its advantages and importance in the faculty's professional development in further education. Taken separately, each of them is assessed as separate elements of continuous education with definite functions and different contribution to the faculty's professional development in the field of pedagogical performance. Synthesizing the theoretical approaches analysed and the international experience in implementing the faculty's further education, the assumption was expressed that further education ensuring the faculty's professional development is implemented if all the described organizational forms of learning are integrated and viewed in a system holistically. Figure 1 presents the holistic approach to further education that ensures the university faculty's professional development.

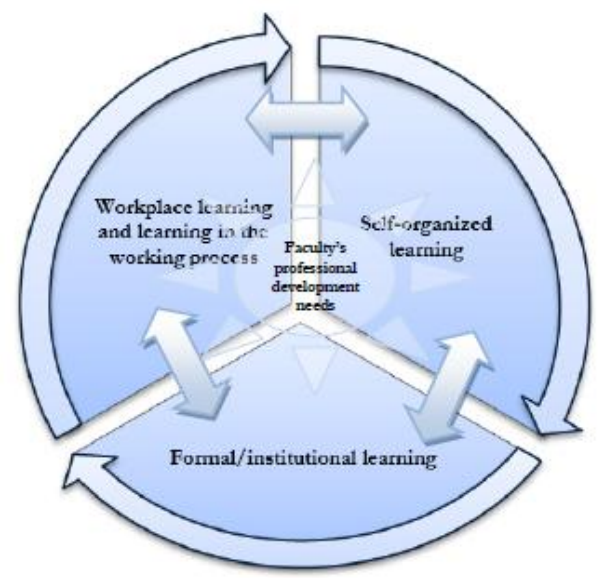

Figure1. Conceptual basis of the holistic approach to the professional development of the academic staff in further education

Source: [6] 
The aim of this conception is to develop the further education system of the academic staff in the University of Latvia which would offer opportunities of dynamic formal/ institutionalized learning, workplace learning and self-organized learning.

Transformation of further education of the academic staff according to the holistic approach has not yet entirely taken place in the University of Latvia; however, last two years have shown considerable effort on the part of the University administration to promote and support the development of the academic staff in the field of pedagogical performance. It is based on the offer of formal further education programmes, the purposeful workplace learning and more conscious self-organized learning of the academic staff is still to be facilitated establishing faculty's further education as a system.

In general in Latvia professional development of the academic staff is offered in four universities only (see table 1). In 2014 the professional development centres of the academic staff were established in two universities: Centre for Tertiary Didactic of the Faculty of Education, Psychology and Art of the University of Latvia [18] and Riga Stradins University Centre for Educational Growth that later were developed into the Faculty of Further Education [19]. The aim of the respective structural units of these universities is to ensure professional development for the academic staff in the field of pedagogical activities. Further education programmes targeted at academic staff are developed and offered by both the centres. RSU further education offer is oriented only to its own academic staff. The target audience of the University of Latvia is broader because its centre offers professional development to University of Latvia academic staff, doctoral students as well as the faculty of other higher education institutions of Latvia.

Riga Technical University offers the professional development module programme to the academic staff of the higher education institutions of Latvia. The length of the programme "Improvement of the faculty's competences in the field of pedagogy and IT" is 160 hours of which the number of contact hours depends on the previous experience in the field of pedagogy and IT (40/72 hours). The programme is offered in four modules: "Changes in education in the context of philosophy, psychology and sociology", "Modern teaching and learning theories and their expression in the study process", "Solutions of information technologies in support of the study process" and "Key competences of the academic staff".

The University of Agriculture of Latvia [20], offers the professional development programme for the university faculty "Innovations in university didactics". This programme is implemented in the form of modules (one module is four academic hours), 10-16 modules have to be selected over the period of six years. In order to receive the professional development certificate each course participant has to defend the course paper. Alternatively international mobility activities, participation in conferences and seminars related to the topic of professional development in the total amount of 96-120 hours also counts for the certificate.

Table1. The offer of professional development programmes for the academic staff in Latvia

\begin{tabular}{|c|c|c|}
\hline University & \begin{tabular}{|c|} 
Further education courses \\
\end{tabular} & Brief description \\
\hline $\begin{array}{l}\text { University of } \\
\text { Latvia }\end{array}$ & $\begin{array}{l}\text { "University didactics: modern theories and } \\
\text { practice" (160 academic hours that is partly } \\
\text { implemented in e-study environment) } \\
\text { "Introduction to university teacher's work" } \\
\text { (64 contact hours) } \\
\text { "Formulation of the learning outcomes and } \\
\text { methods of their assessment" ( } 10 \text { academic } \\
\text { contact hours) } \\
\text { "Pedagogical aspects of developing study } \\
\text { programmes in higher education" ( } 10 \\
\text { academic contact hours) } \\
\text { "Professional development of the student } \\
\text { curator's competence" ( } 32 \text { contact hours) } \\
\text { "Integrated content and academic English } \\
\text { acquisition" ( } 32 \text { contact hours) }\end{array}$ & $\begin{array}{l}\text { The aim of implementing the } \\
\text { programmes is ensuring diverse offer in } \\
\text { the field of university didactics based on } \\
\text { the research of the faculty's professional } \\
\text { needs. }\end{array}$ \\
\hline $\begin{array}{l}\text { Riga Technical } \\
\text { University }\end{array}$ & $\begin{array}{l}\text { "Improvement of the academic staff's } \\
\text { competences in the field of pedagogy and IT" } \\
\text { (160 hours of which the number of contact hours } \\
\text { depends on the previous expereince in the field } \\
\text { of pedagogy and IT ( } 40 / 72 \text { hours) })\end{array}$ & $\begin{array}{l}\text { The aim of the programme is to acquaint } \\
\text { the academic staff with the trends of } \\
\text { modern university didactics in the context } \\
\text { of philosophy, psychology and sociology } \\
\text { and to encourage for creative pedagogical }\end{array}$ \\
\hline
\end{tabular}


Challenges in Transformation of the Professional Development of Academic Staff in Latvia

\begin{tabular}{|c|c|c|}
\hline University & Further education courses & Brief description \\
\hline & & $\begin{array}{l}\text { activity, to activate and improve the } \\
\text { pedagogical copetence selecting the } \\
\text { teaching/learning methods and technical } \\
\text { solution for ensuring the pedagogica } \\
\text { l process: delivery of lectures and } \\
\text { developing of the study materials. }\end{array}$ \\
\hline $\begin{array}{l}\text { University of } \\
\text { Agriculture of } \\
\text { Latvia }\end{array}$ & $\begin{array}{l}\text { "Innovations in university didactics" (60 } \\
\text { academic hours, including 40-64 contact hours) }\end{array}$ & $\begin{array}{l}\text { The aim of the programme is to improve } \\
\text { the participants' knowledge in university } \\
\text { didactics and its application possibilities } \\
\text { in pedagogical activity promoting the } \\
\text { evaluation of theoretical ideas and } \\
\text { practical performance and introduction of } \\
\text { innovations in pedagogical work; to } \\
\text { improve knowledge about the higher } \\
\text { education development strategy in Latvia } \\
\text { in the EU context; to encourage } \\
\text { continuous professional development in } \\
\text { university didactics. }\end{array}$ \\
\hline $\begin{array}{l}\text { Riga Stradins } \\
\text { University }\end{array}$ & $\begin{array}{l}\text { "Information literacy and electronic } \\
\text { resources in medicine." ( } 15 \text { hours) } \\
\text { "Positive communication and formation of a } \\
\text { confident self-image in efficient interaction." } \\
\text { ( } 8 \text { hours }) \\
\text { Professional development courses in the } \\
\text { speciality. The duration varies from five to } 50 \\
\text { hours per course. }\end{array}$ & $\begin{array}{l}\text { To develop further education } \\
\text { programmes for the professional } \\
\text { development of the academic staff and } \\
\text { specialist in medicine. }\end{array}$ \\
\hline
\end{tabular}

Source: The authors, based on information from [19]; [20]; [25]; [26]

The University of Latvia offers the widest range of the pedagogical professional development programmes for the academic staff, most of all taking into consideration also the heterogeneity of the academic staff as the target group (e.g., new university teachers and teachers with university pedagogical experience) and diverse professional development needs. The case of the institutionalization of the University of Latvia faculty's further education will be described in detail further in the paper.

\subsection{Challenges of Professional Development at the University of Latvia}

The interview results are summarized in Table 2 and the findings stemming from the interviews are analyzed further in the text.

Table2. The experience of the academic staff of the UL in the field of professional development

\begin{tabular}{|c|c|}
\hline $\begin{array}{l}\text { Challenges in the } \\
\text { work of the } \\
\text { university teacher }\end{array}$ & $\begin{array}{l}\text { - Student-centred study process } \\
\text { - Changes in the organization culture in the university } \\
\text { - Policy implications in the study process in the context of forming the common } \\
\text { European higher education area } \\
\text { - Internationalization and mobility } \\
\text { - Balance between teaching and research } \\
\text { - Modernization of the study process (incl. digitalization) }\end{array}$ \\
\hline $\begin{array}{l}\text { Professional } \\
\text { development needs } \\
\text { of the university } \\
\text { teachers }\end{array}$ & $\begin{array}{l}\text { - Skills of foreign languages (mainly English) for academic needs } \\
\text { - Communication skills in the intercultural context } \\
\text { - Digital literacy } \\
\text { - Stress management } \\
\text { - Implementation of the student-centred study process: from understanding to action }\end{array}$ \\
\hline $\begin{array}{l}\text { Necessary } \\
\text { transformation in } \\
\text { further education }\end{array}$ & $\begin{array}{l}\text { - Further education as a holistic system in the organization culture of the university } \\
\text { - Institutional and individual synergy for promoting purposeful professional } \\
\text { development of the academic staff } \\
\text { - Further education offer corresponding to the diverse professional development } \\
\text { needs of the academic staff } \\
\text { - Professional development of the academic staff as an integral part of the } \\
\text { professional activity }\end{array}$ \\
\hline
\end{tabular}

Source: The authors 
At present there are 56 higher education institutions in Latvia but the University of Latvia is the only classic type university in the country. [21]. The ideas of professional development of the academic staff in the field of pedagogical performance at the University of Latvia were activated immediately after regaining Latvia's independence in the 90 s of the 20th century in the context of introducing changes in all spheres of public activities. Gaining the international experience and learning from it already since the beginnings of the 90s the professional development of the University of Latvia academic staff has been promoted and the work on improving the professional qualification of the academic staff of higher education institutions of Latvia has been facilitated developing gradually formal further education programmes for the academic staff. Professional development of the University of Latvia faculty has been promoted by the participation in international projects (e.g., TEMPUS), the cooperation with higher education institutions of Austria, Sweden, Finland, Estonia, Poland and Slovenia. The international cooperation resulted in the development of three professional development programmes for university teachers: "Foundations of pedagogical education of university faculty", "Pedagogical development of the university faculty" and "University didactics: modern theories and practice" that were approved by the Senate of the University of Latvia [22].

In autumn 2009 University of Latvia developed another programme "Faculty's professional competences for the innovations in the European Higher Education Area" based on the demand from the academic and administrative staff to better understand the challenges stemming from the Bologna process. In addition the further education programme "University didactics: modern theories and practice" was developed those faculty who had already acquired some professional development programmes.

One of the indicators in the University of Latvia Strategic plan [23] regarding the academic staff has been defined as follows: "by 2014 University of Latvia establishes the support structure for the academic staff for the acquisition of the latest methodology, didactics and technologies as well as takeover of the best experience". Thus the existing further education programmes for the faculty were optimized by eliminating their fragmentation. In 2013 substantial changes were introduced to strengthen the institutionalization of further education and the Centre for Tertiary Didactic was established at the Faculty of Education, Psychology and Art. [24]. The aim of the Centre is to provide professional development for the academic staff, doctoral students of higher education institutions of Latvia and adult educators [18]. The objectives of the Centre among other things include offering the professional development courses; researching the field of university pedagogy including the faculty's professional needs; providing informative, consultative and methodological support to the university faculty in the field of university didactics [18]. Thus University of Latvia became the first higher education institution in Latvia which had institutionalized the professional development of the academic staff.

At present the capacity of this structural unit is limited because activities of the centre largely are based on the initiative of six people who themselves are the University teachers and the financial support comes only from the self generated income and University of Latvia academic development projects that is not sufficient to ensure permanent staff for the centre able to work out and implement further education programmes.

Today the Centre has developed and offers 7 professional development and further education programmes (see table 1) for the academic staff of the higher education institutions and colleges of Latvia.

The experience of the Centre indicates that small-size workshops in which the participants have an opportunity to learn the topicalities of the university pedagogy and to act themselves by modelling the study process are on great demand.

Now preparing for the repeated accreditation of the study directions in higher education institutions of Latvia in 2019 the issue about the essence of formulating the learning outcomes has become topical. The faculty of higher education institutions of Latvia when formulating the learning outcomes have not always understood sufficiently their role in the study process (promotion of the dialogue with the student, implementation of the student-centred study process, importance of learning outcomes in assessment) and have formulated them more formally as norms expressed in the 'has to be' form during the previous accreditation periods of the study programmes. During the last academic years several higher education institutions and colleges have asked the Centre to organize further education courses for their faculty about the methods of formulating the learning outcomes and assessment. 


\subsection{Key Challenges and Changes in the Work of University Faculty over the Last 10 Years}

Respondents mention the student-centred study process as one of the topical challenges in the work of the university faculty nowadays and student-centred studies also envisage changes in the didactics of the study courses. The academic staff has a very different understanding about it. Another important challenge is also the orientation of the study process to the learning outcomes. Experts of all the fields mention the digitalization and internationalization of the study process as important challenges that create objective needs for the faculty to improve the foreign language skills, communication skills in the intercultural context and digital literacy. The expert in the field of education sciences emphasizes: "The activity of the university has transformed from the "place" to the "space" - the university teacher works in the virtual space and does it on the international scale." The challenge for the faculty is also the ability to be the role model to students - the future, new specialists of the field.

All experts indicate that one of the interesting challenges in the work of the faculty is the cooperation of the university with schools or the previous stage of education, not only so that the pedagogical cooperation of the university teacher and the student is successful but also to attract new students to the university. It has to be taken into consideration that the competence for students in the field of higher education is not only among the higher education institutions of Latvia but especially with higher education institutions of European countries.

The representative of the education sciences indicates that working with the pre-service teachers student-centred approach has to be keep in mind: "Thus working with the future teachers the university teacher has to perform a double task- the new teachers' competence to implement the competence approach at school has to be promoted in the student-centred study process". The representative of the social sciences also admits that "hearing that in 2017 Latvia has started implementing the reform of general education system "The competence approach in the teaching/learning content" there emerges a question - whether and how the competence approach can be implemented in higher education? What do the academic staff in higher education institutions understand by it? How is and how will the succession be ensured from the previous level of education?

The scope of responsibilities and their diversity for the university teachers have increased significantly over the last 10 years. The key types of performance - research and study work keep their relevance but different organizational tasks in professional work of every university teacher take an increasingly larger share. The expert on humanities and social sciences admits that the faculty's research work is institutionally more stimulated by the university because those indicators are more important for the external assessment of the institution, e.g., university rankings while the professional development in the field of pedagogical performance is often left as the faculty's own responsibility.

Experts on humanities and social sciences acknowledge that the university teachers themselves have to be able to attract resources for research projects that take a lot of time and resources that the academic staff could use directly in their research related activities. The expert on sciences, life sciences and medicine states directors of study programmes need more support from the university administration when they are developing and updating the study programmes. He mentions that sometimes the contribution of the academic staff for the time of preparing for lectures is only partly or is not at all included in their work load calculations and thus they are not adequately paid for these activities.

From the literature and experts interviews follows that for the faculty's professional performance the main challenges are the implementation of the student-centred study process, the balance between the study work and research, and the change management in the university.

\subsection{Topical Needs of the Faculty's Professional Development}

All in all, the topical needs of the professional development are described as very diverse and they are determined by the current situation in the university practice and the society in general.

The expert in the field of education sciences shares her reflections: "Sometimes I have the feeling that my professional competence actually is incomplete- it is insufficient, it has to be improved continuously. This creates a kind of a stress situation. It seems I cannot cope with all my professional requirements. Thus one of the faculty's topical needs is stress management. The university teacher has to understand how to manage changes as such". The expert also points out the necessity to improve the faculty's foreign language skills and digital didactic skills. 
The expert in the field of social sciences draws attention to the necessity of learning and improving the skills of the academic foreign language, mainly the English language. She has perfected herself during this term attending the further education course "English Language Training of Academic Staff for Research and Academic Purposes (B2 level)" implemented by the Faculty of Humanities, University of Latvia.

Representatives of the academic staff in the field of social sciences, sciences, life sciences and medicine consider that it is essential for the faculty to improve their ability to encourage students to do more themselves, to understand that they also have independent work outside the contact hours and how this contributes to their development as specialists. Thus the faculty has to be able to give students such tasks that facilitate the independent work. They admit that sometimes there still exists the approach - "I will teach you all this" which does not allow implementing validly the studentcentred approach in Latvia.

The representative of the humanities admits that the professional development needs of the faculty who work in the fields where it is typical have a small number of students in the lecture room will definitely differ from those fields where usually there are numerically large audiences. The expert in the field of sciences, life sciences and medicine also mentions that in situations where studies mainly focus on practical activities the faculty has to organize the study process so that students are actively involved themselves. Professional development needs of the faculty who, firstly, are practitioners and the most of their workload is constituted by work, e.g., in the hospital or school will also differ from the needs of those whose basic work is in the university only.

The expert in the field of social sciences considers that the evaluation of student feedback serves as a good source of information on the direction in which the faculty's professional development is needed. However, the question how these data are processed, how much the faculty are taking them into account, how the programme director are using them remains open. She admits that she as the programme director finds it difficult to discuss student feedback results with the faculty whose work had been assessed critically (especially, if the university teacher has rich experience, is older or recognized specialist in the field).

According to the experts interviewed each university teacher is aware of the topical professional development needs based on the professional challenges their encounter during teaching. However, the academic staff cannot receive the personally needed professional development because the respective courses are not offered.

From the analysis of the experts interviews can be concluded that the university should systematically explore the faculty's professional development needs and offer purposefully the professional development opportunities according to these needs.

\subsection{Necessary Changes in the Faculty's Further Education}

Speaking about the changes necessary in the further education of the academic staff, the expert in the field of education sciences points out that as the University of Latvia visions itself as the research university it primarily supports the development of its research related infrastructure (the use of data bases, the use of data processing methods, etc.) but systemic support of the development of professional competence in of the faculty of all levels emphasizing teaching, i.e., the pedagogical aspect would also be needed.

Representatives of the education sciences and humanities admit that it would be advisable also to pay attention to the professional development of professors as currently the professional development courses are oriented to mainly to the junior faculty.

The representative of the social sciences stresses the necessity to ensure the accessibility to the professional development to the entire faculty, underlining that further education should be free of charge in one's own university: "Unfortunately, for instance, the acquisition of the English language courses has to be financed by the university teachers themselves. At present on the university administration level it has been defined in different meetings and it has been written also in the strategic documents that the professional development of the academic staff is necessary but at the same time there are not enough opportunities and the professional development is not included in the normative documents calculating the workload. Achievements in research are more expected from the faculty but the professional development in the field of pedagogical performance is allotted a secondary importance." 
Representatives of the humanities, sciences, life sciences and medicine point at the necessity to involve representatives of different fields who know best the specifics of methods in their fields in working out the further education offer for the faculty.

The expert in the field of sciences, life sciences and medicine mentions that attending courses of the professional development at the University of Latvia have improved teaching skills of academic staff. For example, principles of formulating the learning outcomes that were before unclear to many university teachers were acquired in the offered programmes.

All experts draw attention to the necessity for each university teacher to be able to formulate efficiently the learning outcomes and to assess the student achievements. The participation in the programme facilitated collegial discussions, the exchange of experience that otherwise is not used in daily work.

The expert of social sciences emphasises that students during their studies are also are full time employed elsewhere because of the socioeconomic situation in the country. Thus, sometimes it is difficult to understand what the priority of students is: to study or to work. Can such a situation be considered a good excuse and "be the reason for degrading the value of higher education?" In this context it is named the necessity for the digitalization of the study process, but at the same time also the essence of face-to-face learning is underlined because "one cannot expect that the new professionals will be able to function successfully in the society if they had studied only on-line".

A significant benefit of the faculty's further education is the promotion of their cooperation by eliminating the overlapping of the study courses, promoting better coordinated organizational forms of the study process, coordinating more the tasks that are given for students' independent work.

Experts in the field of education sciences, social sciences and sciences point at the lack of time for the faculty to improve in a self-organized way. Therefore the idea that the faculty's professional development has to be recognized as an integral part of the faculty's professional performance is strengthened even more.

\section{Conclusions}

Key normative documents of the higher education system of Latvia regarding the faculty's professional development are stems from the documents of the Bologna process and recommenddations of the European Commission. Latvia in the framework of the Bologna process has taken upon itself to act in the higher education quality assurance processes in accordance with the European Standards and Guidelines for Quality Assurance (ESG), which is the key document of the quality assurance in the European Higher Education Area (EHEA).

Although the faculty's professional development in the teaching-learning field in the Europeanization context of higher education in Latvia is viewed as a significant prerequisite of assuring quality in higher education (on the political and administrative level of higher education institutions) it is not always reflected in the institutional action.

It is possible to state that the most important challenges for the faculty's professional development in Latvia are: keeping balance between study process and research, the student-centred study process, the modernization (incl. digitalization) of the study process, changes in the organization culture, and Europeanization and internationalization aspects of higher education.

Faculty's professional development has to be looked upon in the context of the institutional development. The required minimum of professional development of the academic staff at least once in a six year period is defined by the legislation of Latvia. However, the defined minimum is not sufficient to cover all the needs of the academic staff. Therefore the further education offered to the faculty should become dynamic, flexible; relevant to the faculty's professional needs. It is advisable that universities commence educating their own specialists in the field of professional development. It is not enough during professional development activities to provide academic staff with the theory on how to teach their courses, it is necessary to establish the consultative support system of the faculty's professional performance, to organize practical workshops in which to try out new teaching methods, approbate the experience. Besides it is advisable to consider further education an integral part of the faculty's workload, but not as supplementary activities to which the university teachers devotes their time outside the direct university duties. Further education of the academic staff is both the individual 
responsibility of each university teacher and the institutional responsibility of the higher education institution that has to be implemented applying three organizational forms of learning in adult education: formal further education, workplace learning and self-organized learning. Institutional responsibility is to offer systematic further education opportunities for professional development accordance with the needs of each university teacher.

The case study of the University of Latvia reveals that university teachers after the acquisition of those programmes attain the change in their understanding of the academic tasks and expected study outcomes. The professional development in the field of pedagogical performance should become the central issue of each higher education institution, professional development activities should be organized in all higher education institutions of Latvia not only in four of them as it is currently. The faculty's professional development should be organized as a systemic part of the development strategy of the higher education institution and the staff development policy.

\section{ACKNOWLEDGEMENT}

The study the implementation of which led to obtaining these findings has received funding from Norway Grants Programme 2009-2014 in accordance with the project, EU policies impact to the transformations of the higher education and research system in Norway and Latvia" agreement No NFI/R/2014/006

\section{REFERENCES}

[1] Report to European Commission Improving the Quality of Teaching and Learning in Europe's Higher Education Institutions. High Level Group on the Modernisation of Higher Education. Luxembourg: Publications Office of European Union. (2013). Retrieved from: http://ec.Euro pa.eu/education/library/reports/modernisationen.pdf [Retrieved 16.09. 2016]

[2] Fanghanel, J. Being an academic. London and New York: Routledge Taylor\&Francis Group. (2011).

[3] Eggins, H. Globalisation and Reform in Higher Education. Berkshire, GBR: McGraw-Hill Education. (2003).

[4] Brunner, J. J. Latvia.Higher Education: Changing Conditions, Problems, Challenges and Policy Options. Washington, DC: World Bank.(2003).Retrieved from:http://documents.worldbank.org/ curated/en/351101468774548648/pdf/311250ENGLISH0LV0Higher0Education.pdf[Retrieved 07.09.2016]

[5] Rubene, Z. Kritiskā domāšana studiju procesā. [Critical thinking in the study process] Rīga: LU Akadēmiskais apgāds. (2008).

[6] Baranova, S. Augstskolu docētāju profesionālā pilnveide tālākizglītībā. [Professional development of the University faculty in further education.] [PhD Dissertation], University of Latvia. (2012).

[7] Mezirow, J. An overview on transformative learning In: Knud Illeris (Ed.) Contemporary theories of learning: learning theorists in their own words. London; New York: Routledge, pp. 90-105. ISBN 9780415473446. (2009).

[8] Dedze, I., Rubene, Z. Universities in Latvia - from the Soviet to European Higher Education Area. Foro de Educación, v. 14, n. 21, pp. 13-38. e- ISSN: 1698-7802 DOI: http://dx.doi.org/ 10.14516/fde.2016.014.021.002. (2016, July-December). Retrieved from: http://forode educa ction.com/ojs/index.php/fde/article/view/470

[9] Report to European Commission New modes of learning and teaching in higher education. High Level Group on the Modernisation of Higher Education. Luxembourg: Publications Office of EuropeanUnion.Doi:10.2766/81897.(2014).Retrievedfrom:http://ec.europa.eu/dgs/educationcultu re/repository/education/library/reports/modernisation-universities_en.pdf[Retrieved16.09. 2016]

[10] Standards and Guidelines for Quality Assurance in the European Higher Education Area. (ESG). Brussels, Belgium. (2015). Retrieved from:http://www.enqa.eu/wp-content/uploads/2015/11/ ESG_2015.pdf [Retrieved 16.09. 2016]

[11] Augstskolu likums [The Law on Higher Education Institutions]. Latvijas Vēstnesis,179 (462). (1995). 
[12] Cabinet Regulations No 662. Noteikumi par pedagogiem nepieciešamo izglītīibu un profesionālo kvalifikāciju un pedagogu profesionālās kompetences pilnveides kārtību [Regulations on the requirements for education and professional qualification of teachers and rules of professional development]. Latvijas Vēstnesis, 219 (5279) Rīga. (2014).

[13] Cabinet Regulations No 347. Noteikumi par prasībām pedagogiem nepieciešamajai izglìtībai un profesionālajai kvalifikācijai [Regulations on the requirements for education and professional qualification of teachers] Latvijas Vēstnesis, 350/352 (2261/2263) Rīga, (2000).

[14] Cabinet Directions No 640. Par koncepciju "Latvijas augstākās izglītības ārējās kvalitātes nodrošināšanas sistēmas pilnveide" [Improvement of the external quality assurance system of higher education in Latvia]. Latvijas Vēstnesis, 221 (5281) Rīga .(2014)

[15] Cabinet Regulations No 407. Augstskolu, koledžu un studiju virzienu akreditācijas noteikumi. [Regulations on the accreditation of higher education institutions, colleges and study directions] Latvijas Vēstnesis, 146 (5464) Rīga, (2015).

[16] EHEA Ministerial Conference. Yerevan Communiqué. (2015). Retrieved from: http://media. ehea.info/file/2015_Yerevan/70/7/YerevanCommuniqueFinal_613707.pdf

[17] Golubeva, A. Studiju programmas direktora kā vadītāja darbības kompetence un profesionālā pilnveide. [Action competence and professional development of the director of the study programme as the leader.] [PhD Dissertation], University of Latvia. (2010)

[18] Latvijas universitātes Pedagogiijas un psihologijas fakultātes Augstskolu Didaktikas Centra nolikums. [Centre for Tertiary Didactic of the Faculty of Education, Psychology and Art of the University of Latvia] Rīga: Latvijas Universitāte. (2013)

[19] RSU Profesionālās pilnveides kursi [Professional development courses]. Riga Stradins University. (n.d). Retrieved from: http://www.rsu.lv/fakultates/talakizglitibas-fakultate/ profesionalapilnveide [Retrieved 22.01.2017]

[20] Augstākās izglītîbas pedagogu profesionālās pilnveides programma „Inovācijas augstskolas didaktikā". [Tertiary professional development programme "Innovations in university didactics"] Jelgava: Latvijas Lauksaimniecības universitāte. (n.d.).

[21] Augstākās izglîtības, zinātnes un inovāciju departaments. Pārskats par Latvijas augstāko izglītîbu 2015.gadā. Galvenie statistikas dati. [Ministry of Education and Science Department of higher education, science and innovations. REPORT of higher education of Latvia in 2015. Main statistical data] Riga: Ministry of Education and Science. (2016). Retrieved from http://www. izm.gov.lv/ images/izglitiba_augst/Parskats_2015.pdf [Retrieved 16.09.2016]

[22] Par augstākās izglīitības pakāpē strādājošo pedagogu profesionālās pilnveides programmām. [On the professional development programmes of teachers working on the tertiary level. University of Latvia, decision of the Senate Nr. 121]. LU Senāta lēmums Nr.121. Rīga: Latvijas Universitāte. (2002).

[23] Latvijas Universitātes Stratēǵiskais plāns 2010. - 2020. gadam. Apstiprināts ar LU Senāta 24.05.2010. lemmums Nr. 370. [University of Latvia Strategic plan 2010-2020. Approved with the decision of the UL Senate Nr, 370, 24.05.2010] Rīga: LU Akadēmiskais apgāds. (2010).

[24] Par Augstskolu Didaktikas Centra Pedagoǵijas un psihologijas fakultātē. [On the Centre for Tertiary Didactic at the Faculty of Education, Psychology and Art. University of Latvia, Direction of the Rector Nr. 1/48. 13.02.2014] Rīga: Latvijas Universitāte, (2014).

[25] Pedagoǵijas un psiholog̣ijas fakultātes Augstskolu Didaktikas Centra īstenotās programmas [Centre for Tertiary Didactic at the Faculty of Education, Psychology and Art. Study Programmes Offered]. (n.d.). Retrieved from: http://www.ppmf.lu.lv/par-fakultati/ strukturvieni bas/centri/augstsk-didakt/programmas/

[26] RTU Profesionālās pilnveides kursi "Akadēmiskā personāla kompetenču pilnveide pedagogijas un IT jomā". [Professional development courses "Improvement of the academic staff's competences in the field of pedagogy and IT"] Rīgas Tehniskā Universitāte Humanitārais institūts.(n.d.). Retrieved from http://huminst.rtu.lv/lv/kursi [Retrieved 09.12 2016] 


\section{AUTHORS' BIOGRAPHY}

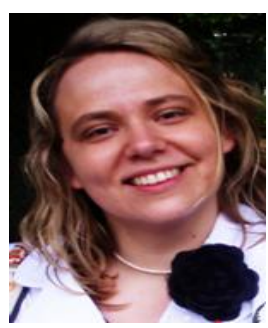

Sanita Baranova, is a Docent (assist. prof.) and researcher of the Faculty of Education, Psychology and Art, University of Latvia; head of the Centre for Tertiary Didactics, Faculty of Education, Psychology and Art, University of Latvia.

From 2001-2007 she has studied pedagogy at the Faculty of Education and Psychology, University of Latvia. In 2012 she defended the doctoral thesis „Professional development of the university faculty in further education”, and received the Degree of Doctor in Pedagogy (Dr.paed.), sub-discipline: Pedagogy of Higher Education. In 2009 in the framework of the ERASMUS programme she has studied at the University of Leipzig (Germany), in 2013 having received the German Academic Exchange Service (DAAD) young researchers' grant she carried out research in Saxon Centre for Teaching and Learning in Higher Education. Since 2009 she is the member of the Association of Latvian Young Scientists. Interest areas of research: professional development of the university faculty, student's partnership in the study process, quality of higher education, changes in the study process in the European context.

Complete mailing address: Faculty of Education, Psychology and Art, University of Latvia, Jūrmalasgatve 76, Rīga LV1083, Latvia

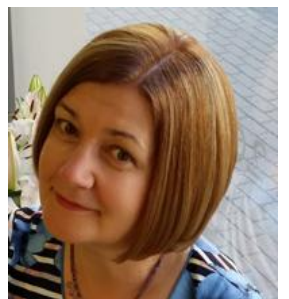

Indra Dedze, has a $\mathrm{PhD}$ degree in the International Comparative Education from Stockholm University. Worked for several NGO's - the Soros Foundation Latvia, Centre for Public Policy PROVIDUS in Latvia and Open Society Institute in Budapest. In all these organizations was responsible for research projects in the field of Education Policy including cooperation with the NGO networks in Central Asia and Eastern Europe and international organizations. In 2004/2005 as a Fulbright fellow spent at Vanderbilt University, USA and carried out research in evaluation of higher education management. From 2009 to 2013 was a National research coordinator for Latvia for the EUROSTUDENT IV project which collects comparable data on the social and economic conditions of student life in Europe.

Complete mailing address: University of Latvia, Raiņa Blvd. 19, Rīga LV 1586, Latvia

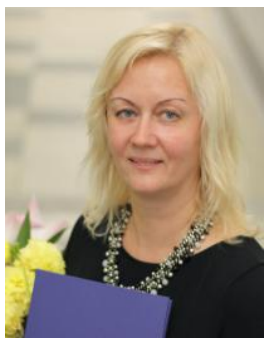

Zanda Rubene, $\mathrm{PhD}$, is a professor of the University of Latvia, director of Doctoral Program in Pedagogy. Author of book Sapereaude! Critical Thinking in University Studies in Latvia (2004) and co-author of books From Knowledge to Competent Activities (2006)and Introduction to Media Pedagogics (2008). Research field:critical thinking,philosophy of education, post-Soviet educational space. There are also several publications on these issues.

Complete mailing address: Faculty of Education, Psychology and Art, University of Latvia, Jūrmalasgatve 76, Rīga LV1083, Latvia 